One further technique of interest which must be mentioned is that of D. M. B. Armstrong, who described a pyknometric technique of following the diffusion of tannins into hide. In this way he has been able to follow the various steps in the tanning process and show that tanning with tannic acid is much more complicated than with Mimosa tannin.

W. J. Marshalt

\section{FIELD STUDIES IN URBAN AREAS}

\section{$\mathrm{T}$}

HE Joint Biology Committee consists of representatives of twelve organizations interested in the teaching of biology. It has now held ten public conferences. While the latest, which was held at University College, London, on October 24, and which was well attended, did not contribute much to the solution of the major problem for which it was convened, it threw light on a number of subsidiary issues which merit attention both by teachers and biologists in general.

In his opening address, R. S. R. Fitter said that although the Industrial Revolution might have driven Nature away from urban areas, there has been a vigorous return. Towns provide special opportunities for the study of processes of biological adaptation to changing conditions. He instanced the house-martin and rock pigeon, dwellers of rocky cliffs, that have taken readily to buildings, and the Oxford ragwort, the natural habitat of which is the lava flows of Sicily but which now is equally at home on sites reduced to rubble by air raids. Town sites tend to encourage a pioneer flora; in fact, modern civilization has greatly extended the area open to plants falling into this group, while upon any site the temporary associations so established are themselves subject to rapid change. He suggested that urban areas provide many opportunities for the study of local geology and geography, together with that of certain plant and animal species. He appreciates the limitations imposed by urban conditions; but he is inclined to view them as a challenge, emphasizing that a great deal still has to be learned about the natural history of even such common animals as the starling and house sparrow.

Miss M. Collis dealt with biology teaching in the secondary modern school, selecting for special consideration the claims of children in the $C$ and $D$ streams who might find it difficult to read and write. Yet work with them she feels to be well worth while. It might begin with sensibly directed observation and collection out of doors, the sorting and disposal in the classroom of the material so collected, leading to further inquiry and exploration and so to the production of records of educational worth. With older pupils the work might be given a more experimental approach, providing further training in the keeping of records while giving the children a clearer conception of the interdependence of living things and the factors that constitute their environment. Miss Hilda Franks, who followed, emphasized that 70-80 per cent of all children pass through secondary modern schools. The teacher's task, she feels, is to put meaning and value into their lives by fostering in them the love of plants and animals. Interest once aroused will provide the basis for more critical standards and so encourage better ways of living. To her it seems that many social ills might be solved through education based on direct contact with real things.
Field studies at grammar schools were discussed by C. T. Prime and W. H. Dowdeswell. Mr. Prime said that at his school, Whitgift, Croydon, biology specialists in the sixth form can elect to take field studies at advanced level in the examination for the General Certificate of Education. Several do so. One difficulty is that the scripts have to be submitted by the beginning of May; another one is that it is not easy for a young investigator to maintain interest in some selected project throughout a whole year. His procedure is to encourage the boys either to make a general biological survey of some fairly restricted area or to set them the task of making a more intensive study of the biology of one or two species of animals or plants. Problems of identification, which are basic, present difficulties, although in his mind they are not insuperable, for several of the smaller groups of animals and plants provide suitable material.

That young biology investigators should not be expected to take on too much was also the opinion of Mr. Dowdeswell. He has found at Winchester College that the survey of a ten-yard stretch of a local stream is the kind of task that they can manage. In his opinion the essential point is to concentrate on ecological principles, which can be brought out from a wide selection of material. He made a special plea for the study of the soil. It is very variable and it lends itself readily to investigation under school conditions. Experiments on its physical nature and mineral composition are comparatively easy to perform, and there are many biotic factors which can be studied in the field and laboratory bringing out the interrelations within the organic complex.

An account of what she is doing at the Children's Centre, and with the Junior Nature Group, at the British Museum (Natural History) was given by Miss J. Palmer. Altogether, during the past five years about three thousand children have passed through her hands, their ages ranging from eight to seventeen with a heavy preponderance around ten and eleven. Three-quarters of the children were boys and a similar proportion were of grammar school standard. Those that visited the Centre were motivated primarily by the urge to collect specimens. She tried to encourage them to draw, paint and model the living organisms in which they were interested and so train them to observe more earefully. Among young children the urge to collect objects is extremely strong, but after twelve it tends to diminish; her aim is to canalize it in the right scientific direction. She is finding that some of her early members are now anxious to remain at the Centre until they reach seventeen, and they are developing into efficient natural historians. While some of the claims made by the children for what they have observed are fantastic, a few are real additions to scientific knowledge.

Several further points emerged from the open discussions. Among those taking part, difficulties over finding time for field-studies were fully appreciated, although they did not always appear to be so by others. Problems concerned with workrooms and other material facilities are not insoluble, given the right kind of teacher, for in the London area education authorities are said to be sympathetic. Nevertheless, it was generally felt that, as was revealed by a recent report issued by the British Association, the field-work done at schools in Great Britain falls far below what is desirable. The lack of field-work is all the more to be regretted because 
personal observation has such a favourable influence on what young pupils have to do ; in examinations, for example, it is a common experience to find diagrams of plant structure slavishly reproduced from text-books. This brought up the question of training. There was an almost unanimous opinion that university courses in biology are not designed to train teachers for their work, particularly in relation to field studies. Some reform of university courses is essential. Little guidance, too, is forthcoming from the usual type of biology text-book.

As indicated above, the day's proceedings did not do much to help the biology teacher in a grammar school situated in the midst of a thickly built-up area. Certain suggestions were made, but they touched only the fringe of the problem, and it appeared as if the best procedure is to arrange for the pupils to attend short courses at field centres in rural areas. Several speakers commented on the waning of interest in living things among boys and girls in the middle range of grammar schools; they attributed this mainly to the pressure of work in preparing for the General Certificate of Education. No comment, however, was made by teachers on the field studies carried out by young people as a purely voluntary, spare-time activity, particularly during the holidays. Studies of this nature may be fostered by school natural history societies. They bring out certain special educational considerations since they are personal and not directed. They are also the purest source of natural history. R. WEATHERALL

\section{POLISH MATHEMATICAL CONGRESS}

'T HE eighth Congress of Polish Mathematicians was held in Warsaw during September 5-12, and was attended, by invitation, by about forty-two mathematicians from outside Poland. There were two British mathematicians present.

The main sections of the Congress were concerned with mathematical logic ; the theory of probability and its applications to statistics; modern mathematical methods, especially those of functional analysis and topology and their application to the classical theory; and the role of mathematics in physics and technology. In addition to the main conferences, held mostly in the morning, there were many sections at which short papers were read.

It is interesting to recall the salient features of the Polish school of mathematics. Before the Second World War this school had two main centres, in Warsaw and Lwów respectively. The Warsaw school was occupied largely with the theory of sets and with mathematical logic, and it was in these two branches that it had its greatest achievements. We owe to the Polish set theorists, in particular, some very beautiful theorems on the topology of the plane, such as the extension to certain classes of continuous functions of a form of Weierstrass's theorem on the decomposition of an integral function into primary factors, and Rouché's theorem on the zeros of a holomorphic function inside a closed contour. These extensions have thrown new light on the topological character of these theorems on functions of a complex variable. The Polish school of mathematical logic is perhaps even better known, for the contributions of Polish mathematicians stand out in practically every branch of this subject.
The most outstanding contributions of the Lwów school were in the domain of functional analysis, with which the name of Banach is so intimately associated. It was Banach's work which laid the foundation for so much of modern analysis, and with his death, in the summer of 1945, the world lost a great mathematician. Under his guidance the mathematical life in Lwów, in the years before the War, was very free and friendly, with mathematical discussions taking place frequently in cafés. One of Banach's institutions was what became known as the "Scottish Book"-a book of problems contributed by the Lwów mathematicians, and any others who happened to be visiting Lwów. It was kept in a café frequented by mathematicians, after which it became known. The result was a very interesting collection of mathematical problems. It has survived the War, and a new "Scottish Book" has been started at Wroclaw, where the Lwow Institute has been re-established.

Polish mathematicians suffered enormous losses during the War. Some fifty-four lost their lives, very many in almost unbelievable circumstances, a loss which represented a ratio of about one in four. Immediately after the Nazi invasion those of Jewish descent were declared outlaws. This meant that some were shot almost at once, while others managed to survive in hiding until the summer and autumn of 1943 , when they were either shot by the Gestapo or sent to the gas chambers. Saks, Schauder, Auerbach, among very many others, perished in this way. Banach and Mazurkiewicz both died within a few months of liberation. Very many of those who died were young men who had yet to make their full contribution to mathematics, and their loss to Polish mathematics is incalculable. Lives lost cannot be replaced; but every effort has been made during the past eight years to do whatever possible to build up the school again. Generous government grants have enabled the various mathematical institutes to re-establish themselves as research centres. At present they are maintaining three journals of international standing, and several others primarily for circulation in Poland. They are also re-issuing the series of "Mathematical Monographs".

The Congress brought out three things very clearly : first, the remarkable continuity in the Polish school; second, the contributions being made by the younger Polish mathematicians, who have grown up in the years since the War; and third, the desire of all for the better exchange of scientific work. It is true that the work of several of the younger men is already known in Great Britain, but more contact is needed between British and Polish mathematicians. Before the War this was partly achieved as a result of the unfortunate necessity for many Poles to seek posts outside Poland. To-day there are plenty of posts for mathematiciars in Poland, and other and happier ways must be found for securing scientific cooperation. It would, for example, be very valuable if some Polish mathematicians were to come to Britain to lecture and hold seminars. Assurances were given at the Congress that for their part they would be very pleased to do so, for they are anxious to develop scientific contact with British mathe. maticians and would, in particular, welcome suitable papers in their journals.

Polish mathematics has a great tradition, and one peculiarly its own, and it is heartening to know that this famous school is re-establishing itself. 